\title{
Response of Integrated Nutrient Management on Growth, Yield and Economics of Indian mustard (Brassica juncea L.) in Chhattisgarh Plains
}

\author{
S.P. Singh*, Savita Aditya and Manisha Choudhary \\ Krishi Vigyan Kendra, Raigarh-496001, India \\ Indira Gandhi Krishi Viswavidyalaya, Raipur (C.G.), India \\ *Corresponding author
}

\begin{tabular}{|l|}
\hline K e y w o r d s \\
Integrated nutrient \\
management, FYM, \\
vermicompost, Mustard
\end{tabular}

\section{A B S T R A C T}

The field experiments were conducted at the Instructional Farm, Krishi Vigyan Kendra, Raigarh (C.G.). During rabi 2016-17on Inceptisol to study the response of integrated nutrient management (INM) on growth, yield and economics of mustard (Brassica juncea L.). The experiment was laid out in randomized block design (RBD) comprising nine treatments with three applications. The results revealed that significantly better growth and yield attributes i.e. plant height $(141.33 \mathrm{~cm})$, no. siliqua plant $^{-1}(249.67)$ and seed yield $\left(1545.30 \mathrm{~kg} \mathrm{ha}^{-1}\right)$ was obtained with combined application of $\mathrm{T}_{5}[\mathrm{RDF}+$ Vermicompost $3 \mathrm{t}$ $\mathrm{ha}^{-1}+$ FYM $5 \mathrm{t} \mathrm{ha}^{-1}+$ Azotobactor + PSB] with all the treatments over control. The application of $\mathrm{T}_{5}\left[\mathrm{RDF}+\right.$ Vermicompost $3 \mathrm{tha}^{-1}+\mathrm{FYM} 5 \mathrm{t} \mathrm{ha}^{-1}+$ Azotobactor $\left.+\mathrm{PSB}\right]$ was also found significantly higher gross cost $\left(30750.00 \mathrm{Rs} \mathrm{ha}^{-1}\right)$ and gross return $(57176.00 \mathrm{Rs}$ $\left.\mathrm{ha}^{-1}\right)$ over rest of the treatments. While, net return $\left(29856.00 \mathrm{Rs} \mathrm{ha}^{-1}\right)$ was significantly higher with application of $\mathrm{T}_{9}\left[75 \%\right.$ RDF + Vermicompost $3 \mathrm{t} \mathrm{ha}^{-1}+\mathrm{FYM} 5 \mathrm{t} \mathrm{ha}^{-1}$ + Azotobactor + PSB] over rest of the treatments except at par with $\mathrm{T}_{5}[\mathrm{RDF}+$ Vermicompost $3 \mathrm{tha}^{-1}+$ FYM $5 \mathrm{t} \mathrm{ha}^{-1}+$ Azotobactor $\left.+\mathrm{PSB}\right]$. The highest benefit cost ratio (B: C ratio) was observed of mustard (3.93) with the application of $\mathrm{T}_{6}[75 \%$ RDF (75: 60:30: $\left.22.5 \mathrm{ha}^{-1} \mathrm{NPKS}\right)$ ].

\section{Introduction}

Rapeseed-mustard is the third important oilseed crop in the world. Indian mustard is important oilseed crop and determinant of agricultural economy of the country. Among the seven edible oilseed cultivated in India, rapeseed-mustard (Brassica spp.) contributes 28.6 per cent in the total production of oilseeds. In India, it is the second most important edible oilseed after groundnut sharing 27.8 per cent in India's oilseed economy. The share of oilseeds is 14.1 per cent out of the total cropped area, rapeseedmustard accounts for 3 per cent to the Gross National Product and 10 per cent to the total value of all Agricultural commodities. In India rapeseed-mustard is grown on an area of 25.6 $\mathrm{m}$ ha with production and productivity of 27.5 $\mathrm{m} \mathrm{t}$ and $1075 \mathrm{~kg} \mathrm{ha}{ }^{-1}$, respectively (Anonymous, 2016). The global production of rapeseed-mustard and its oil is around 38-42 and $12-14 \mathrm{~m} \mathrm{t}$, respectively. India contributes 28.3 per cent and 19.8 per cent in world acreage and production. Due to intensive cultivation and imbalanced and inadequate 
supply of fertilizers accompanied by restricted use of organic manures have made the soils not only deficient in the nutrients, but also deteriorated the soil health resulting in decline in crop response. In order to bring the soil well supplied with all the essential plant nutrients, the organic manures being cheaper and ecofriendly could be the alternative to fertilizers for improving both crop productivity and sustainability of the systems. Integrated use of vermicompost with fertilizers, not only supplies macronutrients but also meet the requirement of micronutrients and maintains physico-chemical properties of soil. Integrated use of nutrient is very essential approach, which not only sustains high crop production over the years but also improves soil health and ensures safer environment. Sulphur is also important element which increases yield attributes resultantly the yield of Indian mustard (Kumar et al., 2011) and also enhanced $\mathrm{S}$ uptake as well as oil content (Singh and Pal, 2011 and Kumar and Trivedi, 2012). Biofertilizers can prove to be an effective low cost technology for the farmers. Thus, there is a need to improve the nutrient supply systems in terms of integrated nutrient management involving the use of fertilizers in conjunction with organic manures and fertilizers.

\section{Materials and Methods}

The field experiments was conducted on mustard during rabi 2016-17 for evaluating the growth and yield response under integrated nutrient management (INM) at the Instructional Farm of Krishi Vigyan Kendra, Raigarh (C.G.). The experimental site is located on the Northern part of Chhattisgarh and lies at $21^{\circ} 54 ' \mathrm{~N}$ latitude and $83^{\circ} 24^{\prime} \mathrm{E}$ longitude with an altitude of $215 \mathrm{~m}$ above the mean sea level (MSL). The soil of the experimental fields was an Inceptisol of silty clay loam texture with $\mathrm{pH} 6.50$, EC $0.13 \mathrm{dSm}^{-}$ 1, organic carbon (OC) $5.0 \mathrm{~g} \mathrm{~kg}^{-1}$, available nitrogen $210 \mathrm{~kg} \mathrm{ha}^{-1}$, available phosphorus $20.83 \mathrm{~kg} \mathrm{ha}^{-1}$, available potash $295 \mathrm{~kg} \mathrm{ha}^{-1}$ and available sulphur $20.53 \mathrm{~kg} \mathrm{ha}{ }^{-1}$. The experiment was laid out in randomized block design comprising nine treatments i.e. $\mathrm{T}_{1^{-}}$ Control, $\mathrm{T}_{2}-\mathrm{RDF}$ (100:80:40:30 $\mathrm{kg} \mathrm{ha}^{-1}$ NPKS), $\mathrm{T}_{3}-\mathrm{RDF}+$ Vermicompost $3 \mathrm{t} \mathrm{ha}^{-1}, \mathrm{~T}_{4}$ RDF + Vermicompost $3 \mathrm{t} \mathrm{ha}^{-1}+$ FYM $5 \mathrm{t} \mathrm{ha}^{-1}$, $\mathrm{T}_{5}-\mathrm{RDF}+$ Vermicompost $3 \mathrm{tha}^{-1}+\mathrm{FYM} 5 \mathrm{t}$ $\mathrm{ha}^{-1}+$ Azotobactor + PSB, $\mathrm{T}_{6}-75 \%$ RDF (75: 60:30:22.5 ha $\left.^{-1} \mathrm{NPKS}\right), \mathrm{T}_{7}-75 \% \mathrm{RDF}+$ Vermicompost $3 \mathrm{t} \mathrm{ha}^{-1}, \mathrm{~T}_{8}-75 \% \mathrm{RDF}+$ Vermicompost $3 \mathrm{t} \mathrm{ha}^{-1}+$ FYM $5 \mathrm{t} \mathrm{ha}^{-1}, \mathrm{~T}_{9}-75$ $\% \mathrm{RDF}+$ Vermicompost $3 \mathrm{tha}^{-1}+\mathrm{FYM} 5 \mathrm{t}$ $\mathrm{ha}^{-1}+$ Azotobactor + PSB with replicated three times. Well decomposed FYM and vermicompost is properly incorporate in soil of experimental site. The $50 \%$ of $\mathrm{N}$ and full dose of $\mathrm{P}_{2} \mathrm{O}_{5}, \mathrm{~K}_{2} \mathrm{O}$ and sulphur was applied as basal dose. Remaining $50 \%$ dose of $\mathrm{N}$ is applied as top dressing. The crop variety was Chhattisgarh Sarson used as a test crop. Five plants were selected randomly from each plot for sampling purposes and observations were recorded. The data regarding growth characters, yield attributes and yield were analysed with statistical tools applied as and when required for the study. Economics of experiment was worked out, net return is the product of gross cost subtracted from gross return while, benefit cost ratio $(\mathrm{B}: \mathrm{C})$ was obtained when gross return divided by gross cost.

\section{Results and Discussion}

\section{Growth and yield attributes}

The data revealed that significant differences were observed in growth and yield attributes with all treatments depicted in table 1 . The maximum plant height $(141.33 \mathrm{~cm})$ and no. siliqua plant ${ }^{-1}$ (249.67) was recorded with $\mathrm{T}_{5}$ $\left[\mathrm{RDF}+\right.$ Vermicompost $3 \mathrm{t} \mathrm{ha}^{-1}+$ FYM $^{2} \mathrm{t} \mathrm{ha}^{-1}$ + Azotobactor + PSB] which was significantly superior with all the treatments over control, 
where treatments were integrated with organics and bio fertilizers. Similar finding was also reported by Tripathi et al., (2010) and Chandan et al., (2018). The no. of seeds siliqua $^{-1}$ had no significant response to different treatments. The results indicate that the highest plant height $(141.33 \mathrm{~cm})$ was recorded with $\mathrm{T}_{5}[\mathrm{RDF}+$ Vermicompost $3 \mathrm{t}$ $\mathrm{ha}^{-1}+$ FYM $5 \mathrm{t} \mathrm{ha}^{-1}+$ Azotobactor + PSB] followed by $\mathrm{T}_{9}[75 \% \mathrm{RDF}+$ Vermicompost $3 \mathrm{t} \mathrm{ha}{ }^{-1}+$ FYM $5 \mathrm{t} \mathrm{ha}^{-1}+$ Azotobactor + PSB] $(139.99 \mathrm{~cm})$ and $\mathrm{T}_{4}[\mathrm{RDF}+$ Vermicompost $3 \mathrm{t}$ $\mathrm{ha}^{-1}+$ FYM $\left.5 \mathrm{tha}^{-1}\right](136.55 \mathrm{~cm})$.

The results showed that the use of $25 \%$ reduced quantity of NPK with organics and bio-fertilizers proved better combination in terms of seeds siliqua- 1 . The similar finding was also reported by Singh and Singh (2006), Rundala et al., (2013) and Thaneshwar et al., (2017). The maximum no. of siliqua plant ${ }^{-1}$ (249.67) was recorded with $\mathrm{T}_{5}[\mathrm{RDF}+$ Vermicompost $3 \mathrm{t} \mathrm{ha}^{-1}+$ FYM $5 \mathrm{t} \mathrm{ha}^{-1}+$ Azotobactor + PSB] followed by $\mathrm{T}_{9}[75 \%$ $\mathrm{RDF}+$ Vermicompost $3 \mathrm{t} \mathrm{ha} \mathrm{a}^{-1}+\mathrm{FYM} 5 \mathrm{t} \mathrm{ha} \mathrm{a}^{-1}$
+Azotobactor + PSB] (238.33) and $\mathrm{T}_{4}[\mathrm{RDF}+$ Vermicompost 3t ha $\mathrm{ha}^{-1}$ FYM 5t $\left.\mathrm{ha}^{-1}\right]$ (238.33), where treatments were integrated with organics and biofertilizers. Similar finding was also reported by Pal et al., (2008) and Swarup (2010). Data showed that the highest no. of seeds siliqua $^{-1}$ (11.30) was recorded with $\mathrm{T}_{5}[\mathrm{RDF}+$ Vermicompost $3 \mathrm{t}$ $\mathrm{ha}^{-1}+$ FYM $5 \mathrm{t} \mathrm{ha}^{-1}+$ Azotobactor + PSB] followed by $\mathrm{T}_{9}[75 \% \mathrm{RDF}+$ Vermicompost 3 $\mathrm{t} \mathrm{ha}^{-1}+$ FYM $5 \mathrm{t} \mathrm{ha}^{-1}+$ Azotobactor + PSB] (11.10) and $\mathrm{T}_{4}\left[\mathrm{RDF}+\right.$ Vermicompost $3 \mathrm{t} \mathrm{ha}^{-1}$ + FYM $\left.5 \mathrm{t} \mathrm{ha}^{-1}\right]$ (10.80). The results showed that the use of $25 \%$ reduced quantity of NPK with organics and bio-fertilizers proved better combination in terms of no. seeds siliqua ${ }^{-1}$. The similar finding was also reported by Ramesh et al., (2009) and Pal and Pathak (2016). The seed yield of mustard increased significantly with all the treatments over control. The maximum $\left(1545.30 \mathrm{~kg} \mathrm{ha}^{-1}\right)$ and minimum seed yield $\left(765.25 \mathrm{~kg} \mathrm{ha}^{-1}\right)$ were recorded with $\mathrm{T}_{5}[\mathrm{RDF}+$ Vermicompost $3 \mathrm{t}$ $\mathrm{ha}^{-1}+$ FYM $5 \mathrm{t} \mathrm{ha}^{-1}+$ Azotobactor + PSB] and control treatment, respectively.

Table.1 Effect of integrated nutrient management on growth and yield of mustard

\begin{tabular}{|c|c|c|c|c|}
\hline Treatments & $\begin{array}{l}\text { Plant height at } \\
\text { maturity }(\mathrm{cm})\end{array}$ & $\begin{array}{l}\text { No. of siliqua } \\
\text { plant }^{-1}\end{array}$ & $\begin{array}{l}\text { No. of seeds } \\
\text { siliqua }^{-1}\end{array}$ & $\begin{array}{l}\text { Seed yield } \\
\left(\mathrm{kg} \mathrm{ha}^{-1}\right)\end{array}$ \\
\hline $\mathrm{T}_{1}$ [Control] & 118.22 & 158.67 & 8.90 & 765.25 \\
\hline $\mathrm{T}_{2}$ [RDF (100:80:40:30 $\left.\left.\mathrm{kg} \mathrm{ha}^{-1} \mathrm{NPKS}\right)\right]$ & 126.10 & 213.33 & 10.20 & 1255.50 \\
\hline $\mathrm{T}_{3}\left[\mathrm{RDF}+\right.$ Vermicompost $\left.3 \mathrm{t} \mathrm{ha}^{-1}\right]$ & 131.67 & 227.67 & 10.60 & 1375.25 \\
\hline $\begin{array}{l}\mathrm{T}_{4}\left[\mathrm{RDF}+\text { Vermicompost } 3 \mathrm{tha}^{-1}+\mathrm{FYM} 5 \mathrm{t}\right. \\
\left.\mathrm{ha}^{-1}\right]\end{array}$ & 136.55 & 238.33 & 10.80 & 1450.65 \\
\hline $\begin{array}{l}\mathrm{T}_{5}\left[\mathrm{RDF}+\text { Vermicompost } 3 \mathrm{t} \mathrm{ha}^{-1}+\mathrm{FYM} 5 \mathrm{t}\right. \\
\left.\mathrm{ha}^{-1}+\text { Azotobactor + PSB }\right]\end{array}$ & 141.33 & 249.67 & 11.30 & 1545.30 \\
\hline $\mathrm{T}_{6}\left[75 \%\right.$ RDF (75: 60:30:22.5 $\left.\left.\mathrm{ha}^{-1} \mathrm{NPKS}\right)\right]$ & 123.26 & 207.00 & 9.80 & 1075.60 \\
\hline $\mathrm{T}_{7}\left[75 \% \mathrm{RDF}+\right.$ Vermicompost $\left.3 \mathrm{t} \mathrm{ha}^{-1}\right]$ & 128.22 & 218.33 & 10.50 & 1240.35 \\
\hline $\begin{array}{l}\text { T8[75\% RDF + Vermicompost } 3 \mathrm{t} \mathrm{ha}^{-1}+ \\
\left.\text { FYM } 5 \mathrm{tha}^{-1}\right]\end{array}$ & 134.42 & 229.67 & 10.70 & 1325.75 \\
\hline $\begin{array}{l}\text { T }_{9}[75 \% \text { RDF + Vermicompost 3t ha } \\
\left.\text { FYM 5t ha }{ }^{-1}+\text { Azotobactor + PSB }\right]\end{array}$ & 139.99 & 238.33 & 11.10 & 1430.25 \\
\hline $\mathrm{SE}(\mathrm{m}) \pm$ & 0.19 & 0.03 & 0.51 & 0.35 \\
\hline C.D. $(P=0.05)$ & 0.58 & 0.11 & NS & 1.06 \\
\hline
\end{tabular}


Table.2 Effect of integrated nutrient management on economics of mustard

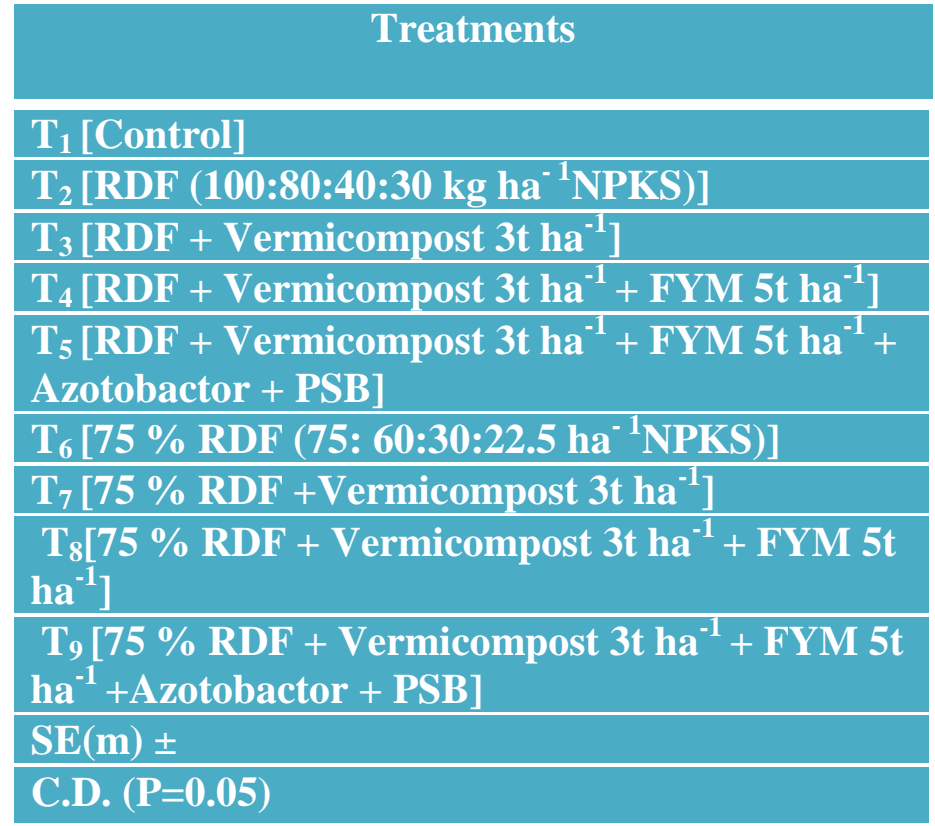

The variation in seed yield was observed due to variation in treatment combinations. The increment in seed yield might be due to improvement in soil quality with the application of vermicompost, farm yard manures, bio fertilizers and instant availability of nutrients from inorganic fertilizers. These finding are also reported by Chandra and Ram (2007) and Saha et al., (2010). The application of reduced quantity of chemical fertilizers along with organics and microbial inoculants gave better results in terms of yield and yield attributing traits and prove better sustainable integrated nutrients management option for farmers.

\section{Economic analysis}

The result indicated that effect of integrated nutrient management (INM) on economics of mustard with various treatments presented in table 2. The maximum gross cost $(30750.00$ $\mathrm{Rs} \mathrm{ha}^{-1}$ ) and maximum gross return (57176.00 Rs $\mathrm{ha}^{-1}$ ) of mustard was recorded with the application of $\mathrm{T}_{5}[\mathrm{RDF}+$ Vermicompost $3 \mathrm{t}$ $\mathrm{ha}^{-1}+$ FYM $5 \mathrm{t} \mathrm{ha}^{-1}+$ Azotobactor + PSB].

\begin{tabular}{|l|l|l|l|}
\hline $\begin{array}{l}\text { Gross cost } \\
\left(\text { Rs ha }^{-1}\right)\end{array}$ & $\begin{array}{l}\text { Gross return } \\
\left(\text { Rs ha }^{-1}\right)\end{array}$ & $\begin{array}{l}\text { Net return } \\
\left(\text { Rs ha }^{-1}\right)\end{array}$ & B:C ratio \\
\hline 8750.00 & 28314.00 & 19564.00 & 3.23 \\
\hline 13500.00 & 46454.00 & 32954.00 & 3.44 \\
\hline 28500.00 & 50885.00 & 22385.00 & 1.78 \\
\hline 30500.00 & 53674.00 & 23174.00 & 1.76 \\
\hline 30750.00 & 57176.00 & 26426.00 & 1.86 \\
\hline 10125.00 & 39797.00 & 29672.00 & 3.93 \\
\hline 21375.00 & 45893.00 & 24518.00 & 2.15 \\
\hline 22875.00 & 49053.00 & 26178.00 & 2.14 \\
\hline 23063.00 & 52919.00 & 29856.00 & 2.29 \\
\hline 0.19 & 17.68 & 0.17 & 0.018 \\
\hline 0.57 & 53.48 & 0.50 & 0.053 \\
\hline
\end{tabular}

The maximum net return (29856.00 Rs ha ${ }^{-1}$ ) of mustard was noted with the application of $\mathrm{T}_{9}\left[75 \% \mathrm{RDF}+\right.$ Vermicompost $3 \mathrm{t} \mathrm{ha}^{-1}+$ FYM $5 \mathrm{t} \mathrm{ha}^{-1}+$ Azotobactor + PSB]. The highest benefit cost ratio (B: $\mathrm{C}$ ratio) was observed of mustard (3.93) with the application of $\mathrm{T}_{6}$ [75 \% RDF (75: 60:30: 22.5 $\mathrm{ha}^{-1}$ NPKS)]. In any case the treatments were highly remunerative and treatments had economic viability in absolute term. There are two considerations in the economic implications, the yield maximization against lower profit and economic maximization at the cost of productivity. The higher productivity means the higher food availability with a marginal sacrifice of monetary return. The findings are in close conformity of Chaurasia et al., (2009) and Singh et al., (2014).

The present study revealed that integrated nutrients management on the basis of above findings it can be concluded that treatment $\mathrm{T}_{5}$ $\left[\mathrm{RDF}+\right.$ Vermicompost $3 \mathrm{t} \mathrm{ha}^{-1}+\mathrm{FYM}^{2} \mathrm{t} \mathrm{ha}^{-1}$ + Azotobactor + PSB] shows the best results with respect to significant growth and yield 
attributes. From the economical point of view, the $\mathrm{T}_{9}\left[75 \% \mathrm{RDF}+\right.$ Vermicompost $3 \mathrm{t} \mathrm{ha}^{-1}+$ FYM 5t ha ${ }^{-1}+$ Azotobactor + PSB] treatment gave higher net return (29856.00 Rs ha ${ }^{-1}$ ) over rest of the treatments. While benefit: cost ratio (B: C) was significantly higher (3.93) with application of $\mathrm{T}_{6}[75 \%$ RDF (75: 60:30:22.5 $\left.\left.\mathrm{ha}^{-}{ }^{1} \mathrm{NPKS}\right)\right]$ over rest of the treatments except being at par with $\mathrm{T}_{5}[\mathrm{RDF}+$ Vermicompost $3 \mathrm{t} \mathrm{ha}^{-1}+\mathrm{FYM} 5 \mathrm{t} \mathrm{ha}^{-1}+$ Azotobactor + PSB]. Therefore treatment $\mathrm{T}_{9}$ [75 \% RDF + Vermicompost 3t ha ${ }^{-1}+$ FYM 5t $\mathrm{ha}^{-1}+$ Azotobactor $+\mathrm{PSB}$ ] is recommended for higher net return in mustard cultivation. The application of reduced quantity of chemical fertilizers along with organics and microbial inoculants gave better results in terms of yield and yield attributing traits and prove better sustainable integrated nutrients management option for farmers.

\section{References}

Anonymous (2016). Agricultural statistics at a glance. DAC Government of India. p. 118.

Chandan, S. K; Singh, S.K; Pandey, A; Singh, P. AND Prabha, Sneh (2018). Effect of integrated nutrient management on growth, yield and nutrient uptake by Indian mustard (Brassica juncea L.). Annals of Plant and Soil Research. 20(1): 31-36.

Chandra, S. and Ram, D. (2007). Effect of integrated nutrient management on yield and nutrient use efficiency in mustard. Indian Journal of Fertilizers 3(5): 5154.

Chaurasia, Anand, Singh A.B. and Namdeo, K.N. (2009). Integrated nutrient management in relation to yield and yield attributes and oil yield of Ethiopian mustard (Brassica carinata). Crop Research. (Hisar). 38 (1/3): 2428.
Kumar, R. and Trivedi, S. K. (2012) Effect of levels and sources of sulphur on yield, quality and nutrient uptake by mustard (Brassica juncea). Progressive Agriculture-An International Journal 12: 69-73.

Kumar, S., Verma, S.K., Singh, T.K. and Singh, S. (2011) Effect of nitrogen and sulphur ongrowth, yield and nutrient uptake by Indian mustard (Brassica juncea). Indian Journal of Agricultural Sciences 81: 145-149.

Pal, R. L and Pathak, J. (2016). Effect of integrated nutrient management on yield and economics of mustard. International Journal of Science and Nature. 7 (2): 255-61.

Pal, Y., Singh, R.P. Sachan, R.S. and Pandey P.C. (2008) Effect of integrated nutrient cropping system. Pantnagar Journal of Research 6 (2): 199-204.

Ramesh, P.; Panwar, N.R.; Singh, A.B. and Ramana, S. (2009). Effect of organic nutrient management practices on the production potential nutrient uptake, soil quality, input use efficiency and economics of mustard (Brassica juncea). Indian Journal of Agricultural Sciences, 79 (1): 40-44.

Rundala, S. R., Kumawat, B. L., Choudhary, G. L., Prajapat, K., Kumawat and Sita (2013) Performance of Indian mustard (Brassica juncea) under integrated nutrient management. Crop Research 46(1-3): p115.

Saha, R., Mishra, V.K., Majumdar, B, Laxminarayan, K. and Ghosh, P. K. (2010) Effect of integrated nutrient management on soil physical properties and crop productivity under a maizemustard cropping sequence in acidic soils of northeast India. Communication of Soil Science and Plant Analysis 41(2): 187- 200.

Singh V., Choudhary S., Verma V.K., Srivastava A.K., Mohd. Aslam and 
Thaneshwar (2014) Studies on integrated nutrient management in mustard [Brassica juncea (L.) Czern \& Cosson]. International Journal of Agricultural Sciences. 10 (2): 667-670.

Singh, Raju and Singh, S.K. (2006). Evaluation of yield and quality aspects of Indian mustard (Brassica juncea L. Czern \& Coss) under integrated nutrient management. Annals of Agricultural Research.27 (3): 220- 223.

Singh, S.P. and Pal, M.S. (2011). Effect of integrated nutrient management on productivity, quality, nutrient uptake and economics of mustard (Brassica juncea). Indian Journal of Agronomy, 56 (4): 381-387.

Swarup Anand (2010) Integrated plant nutrient supply and management strategies for enhancing soil quality, input use efficiency and crop productivity. Journal of the Indian Society of Soil Science.58 (1):25-31.

Thaneshwar; Singh, Vishram; Prakash, Jai; Kumar, Manoj; Kumar, Sateesh and Singh, R.K. (2017). Effect of Integrated Nutrient Management on Growth and Yield of Mustard (Brassica juncea L.) in Irrigated Condition of Upper Gangetic Plain Zone of India. International Journal of Current Microbiology and Applied Sciences 6(1): 922-932.

Tripathi, M.K.; Chaturvedi, Sumit; Shukla, D.K. and Mahapatra, B.S. (2010). Yield performance and quality in Indian mustard (Brassica juncea) as affected by integrated nutrient management. Indian Journal of Agronomy, 55 (2): 138-142.

\section{How to cite this article:}

Singh, S.P., Savita Aditya and Manisha Choudhary. 2018. Response of Integrated Nutrient Management on Growth, Yield and Economics of Indian mustard (Brassica juncea L.) in Chhattisgarh Plains. Int.J.Curr.Microbiol.App.Sci. 7(12): 135-140. doi: https://doi.org/10.20546/ijcmas.2018.712.017 